\title{
USTROJOWE PODSTAWY REALIZACJI POLITYKI ZIELONYCH ZAMÓWIEŃ PUBLICZNYCH
}

\section{CONSTITUTIONAL BASIS OF GREEN PUBLIC PROCUREMENT POLICY}

\section{STRESZCZENIE}

Zamówienia publiczne są istotnym elementem systemu prawno-gospodarczego Unii Europejskiej, jak też poszczególnych krajów członkowskich. Podejmowanie przez państwo działań zmierzających do osiągnięcie optymalnego poziomu dobrobytu przy wykorzystaniu instrumentu zamówień publicznych wymaga uwzględnienia licznych aspektów w tym m.in. konieczności ochrony środowiska. Osiągnięcie zakładanych w dokumentach strategicznych celów związanych z rozwojem zamówień publicznych jest możliwe wyłącznie przy współpracy organów administracyjnych z zamawiającymi m.in. w zakresie dialogu oraz edukacji. Podjęcie próby ukazania ustrojowych podstaw polityki zielonych zamówień publicznych stanowi element konieczny dla podjęcia działań wdrażających. Zamawiający zmierzając do zaspokojenia potrzeb zgodnie z zasadą legalizmu, zobowiązani są bo-

Magister prawa, doktorant na Wydziale Prawa i Administracji Uniwersytetu im. Adama Mickiewicza w Poznaniu, Katedra Prawa Administracyjnego i Nauki o Administracji. 
wiem do podejmowania działań na podstawie i w granicach prawa, w tym zgodnie z Konstytucją RP. Zamawiający w związku z powyższym muszą kształtować swoje działania przy uwzględnieniu koncepcji społecznej gospodarki rynkowej oraz zrównoważonego rozwoju. Ukazanie umocowania ustrojowego podejmowanych działań ma na celu nie tylko zachęcenie do realizacji polityki zielonych zamówień publicznych ale także wskazanie regulacji normatywnych stanowiących podstawę kształtowania w dokumentacji przetargowej zapisów sprzyjających ochronie środowiska.

\section{Słowa kluczowe}

Zielone zamówienia publiczne; zrównoważony rozwój; konstytucyjne podstawy zamówień publicznych.

\section{ABSTRACT}

Public procurement is an important element of the legal-economic system of the European Union, as well as of individual member states. Taking actions to achieve the optimum level of well being by means of public procurement instrument requires consideration of many aspects including the protection of the environment. The achievement of objectives planned in strategic documents, concerning the development of public procurement, is only possible in case of cooperation between administrative authorities and awarding entities, among others in the field of dialogue and education. The attempt to show constitutional basis of green public procurement policy is essential to undertake implementation actions. Awarding entities aiming to satisfy their needs, in accordance with principle of legality, are obliged to take actions on the grounds and within limits of the law, including the Constitution of the Republic of Poland. Therefore, awarding entities must take into account the concept of social market economy and of sustainable development. The indication of constitutional legitimacy of undertaken actions aims not only to encourage the implementation of green public procurement policy but also to show normative regulations which are the base for environmentally friendly regulations in tender documents.

\section{Keywords}

Green public procurement; sustainable development; constitutional foundations of public procurement. 


\section{WPROWADZENIE}

Podejmowanie przez państwo działań zmierzających do osiągnięcie optymalnego poziomu dobrobytu stanowi jeden z najistotniejszych elementów polityki gospodarczej. Osiągnięcie stabilnego poziomu rozwoju gospodarczego wymaga uwzględnienia licznych czynników, w tym między innymi konieczności dbania o środowisko. Powyższe jest tym bardziej istotne, że działalność gospodarcza w sposób nierozerwalny związana jest $\mathrm{z}$ przekształcaniem środowiska przyrodniczego, które jest tym co ekonomiści nazywają niewyłącznym dobrem publicznym ${ }^{1}$. We współczesnej świadomości w wyniku wieloletnich doświadczeń ukształtowało się przekonanie, że sam rynek nie zapewnia ochrony człowiekowi ani środowisku, dlatego we wskazanym zakresie konieczna jest ingerencja administracji publicznej, realizowana w mnogich formach. Jedną z nich jest ukształtowana, przez liczne akty organizacji supranarodowych ${ }^{2}$ oraz krajowych ${ }^{3}$, polityka zielonych zamówień publicznych.

Dotychczasowy ograniczony poziom wdrażania rozwiązań z zakresu zielonych zamówień publicznych ${ }^{4}$ niekorespondują-

1 M. Rudnicki, Ochrona środowiska we wspótczesnej polityce władz publicznych, [w:] Administracja publiczna- człowiek a ochrona środowiska. Zagadnienia społeczno - prawne, M. Górski, J. Bucińska, M. Niedziółka, R. Stec, D. Strus (red.), Warszawa 2011, s. 302.

2 Potencjał ekologicznych zamówień publicznych $\mathrm{w}$ ramach UE podkreślono po raz pierwszy w komunikacie „Komisji Europejskiej na temat zintegrowanej polityki produktowej” z 2003 roku (KOM (2003) 302 wersja ostateczna), w którym zalecono państwom członkowskim przyjęcie do końca 2006 roku krajowych planów działań. Unia Europejska aktywnie wspiera i promuje zielone zamówienia publiczne w kontekście swojej polityki na rzecz zrównoważonej konsumpcji i produkcji. W komunikacie z 2008 roku „Zamówienia publiczne na rzecz poprawy stanu środowiska” (KOM (2008) 400 wersja ostateczna)zatwierdzono określone cele dotyczące zielonych zamówień publicznych, ustanawiając szereg środków wsparcia, które ma wdrożyć Komisja Europejska.

3 Urząd Zamówień Publicznych, Krajowy Plan Działań w zakresie zrównoważonych zamówień publicznych 2013-2016, Warszawa 2013.

4 Pomimo, niskiego poziomu wdrażania rozwiązań zaliczanych do zielonych zamówień publicznych (kształtującego się na poziomie ok. 12\%) na 
cy z treścią dokumentów strategicznych ${ }^{5}$ skłania do poczynienia rozważań, o charakterze podstawowym, ogniskujących się wokół ustrojowych podwalin prośrodowiskowego wydatkowania środków publicznych. Instytucjom zamawiającym brakuje bowiem przede wszystkim wiedzy na temat dopuszczalności stosowania takich kryteriów oraz świadomości korzyści, jakie płyną z realizacji „zielonych zamówień publicznych”. Taki stan rzeczy skutkuje niewystarczającym zainteresowaniem potencjalnych wykonawców lub dostawców kwestiami związanymi z ochroną środowiska. Zdaniem autora ukazanie ważkich kwestii ustrojowych oraz publicznoprawnych jest warunkiem koniecznym udzielenia podmiotom rynku zamówień publicznych odpowiedzi na pytanie o podstawy aksjologiczne oraz normatywne nowego podejścia $\mathrm{w}$ ramach zamówień publicznych. Z kolei, pozyskanie takiej wiedzy jest warunkiem sine qua non zaangażowanego dążenia do osiągnięcia ogólnokrajowych oraz supranarodowych celów strategicznych.

\section{ZAMÓWIENIA PUBLICZNE JAKO INSTRUMENT INGERENCJI PUBLICZNEJ}

Zamówienia publiczne są istotnym elementem systemu prawno-gospodarczego Unii Europejskiej, jak też poszczególnych krajów członkowskich ${ }^{6}$. Całokształt regulacji prawnych

uwagę i pozytywną ocenę zasługuje tendencja wzrostowa. Wzrost poziomu realizacji zielonych zamówień publicznych kształtuje się w szacunkowych granicach 7 proc. z poziomu 4 proc. w 2006 roku do 12 proc. w 2012 roku (ibidem, s. 43-45)

5 Centre for European Policy Studies (CEPS), The uptake of green public procurement in the EU27, Bruksela 2012. Zob. także K. Różowicz, System zamówień publicznych $w$ ochronie środowiska, z uwzględnieniem projektu poselskiego zmian ustawy Prawo zamówień publicznych, http://zlppn.pl/prawo. htm, dostęp: 27 lutego 2015 r.

6 Znaczenie rynku zamówień publicznych obrazują m.in. wskaźniki ekonomiczne wskazujące, iż w 2013 roku wartość rynku zamówień publicznych w Polsce stanowiła ok. 8,76\% PKB, a w Europie aż 19\% PKB Unii Europejskiej. 
z zakresu zamówień publicznych, pomimo wykształcenia wielu swoistych cech, nie funkcjonuje w próżni prawnej, a nadto posiada liczne punkty styczne $\mathrm{z}$ innymi dziedzinami nauk (ekonomią, politologią, socjologią czy też z naukami przyrodniczymi). Podkreślenia wymaga, że struktura oraz natężenie więzi łączącej system zamówień publicznych z różnymi dziedzinami życia społecznego ewoluuje, co można zauważyć m.in. na przykładzie zmiany katalogu celów realizowanych przez państwa poprzez instrument przetargów publicznych. Pierwotnym celem ukształtowania regulacji zamówień publicznych było ujednolicenie procedur dokonywania zakupów przez podmioty sektora publicznego, sprzyjające efektywnemu i gospodarnemu wydatkowaniu środków publicznych, ukształtowanie systemu środków ochrony prawnej oraz kontroli, zapewnienie zainteresowanym wykonawcom równych szans $\mathrm{w}$ dostępie do rynku zamówień publicznych, a w wymiarze negatywnym przeciwdziałanie zjawiskom patologicznym, m.in. korupcji. Prawidłowo zarządzany system zamówień publicznych wpływać miał także na wzrost zaufania społecznego do realizowanych wydatków publicznych.

Ustanowienie odpowiednio sformalizowanej procedury wydatkowania środków publicznych nie było i nie powinno być celem samym w sobie. Optykę, która nakazuje widzieć w regulacjach systemu zamówień tylko i wyłącznie zbiurokratyzowaną procedurę nabywania dóbr, należy uznać za dalece archaiczną. Dostrzeżenie możliwości oddziaływania na rynek poprzez system zamówień publicznych skutkowało stworzeniem odpowiedniego ładu instytucjonalno-prawnego. Wraz z wprowadzanymi zmianami normatywnymi w systemie zamówień publicznych następowało rozszerzenie zakresu dziedzin, na które wpływać miał system wydatkowania środków publicznych (m.in. aspekty socjalne czy też środowiska). Zgodnie z nowym spojrzeniem, zamówienia odgrywają znaczącą rolę w polityce budżetowej państwa umożliwiając wpływanie na gospodarkę. Poprzez wpływanie na rynek podaży, polityka stosowana przez zamawiających może doprowadzić do wzrostu liczby podmiotów aktywnych na danym rynku, jednocześnie wpływając na kształt konkurencji. Zamówienia publiczne mogą także wpływać na wzrost popytu globalnego, czyli sumy wydatków, którą podmioty działające 


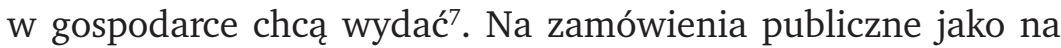
jedną z bezpośrednich metod wpływania na zwiększenie popytu globalnego wskazywał m.in. J. Keynes (obok subwencji czy dotacji) ${ }^{8}$.

Lista celów, jakie współcześnie powinny być realizowane w związku z udzielaniem zamówień publicznych, niewątpliwe zawiera: zapewnienie trwałego i długoterminowego wzrostu gospodarczego, rozwój konkurencyjności przedsiębiorstw, współtworzenie polityki proekologicznej (zielone zamówienia), tworzenie nowych miejsc pracy (społeczne zamówienia publiczne), wspomaganie innowacyjności. Wzmiankowane cele systemu zamówień publicznych wprost przywodzą na myśl konstrukcję interesu publicznego, odgrywającą istotną rolę w procesach stosowania prawa i jego wykładni ${ }^{9}$. S. Dudzik wskazuje, że „pojęcie to pełni funkcję legitymacyjną dla wszelkich działań władzy publicznej, w tym w sferze gospodarki, będąc jednocześnie podstawowym kryterium jej oceny"10.

Zamówienia publiczne są narzędziem polityki gospodarczej i społecznej państwa oraz instrumentem służącym osiągnięciu dodatkowych założeń z zakresu tychże polityk. Korelacja ustawowych założeń $\mathrm{z}$ racjonalnością wydatkowania środków publicznych powinna odnaleźć odzwierciedlenie w ramach konkretnych transakcji. Realizowanie tak bogatej listy celów stanowi przejaw efektywnego wykorzystywania zasobów finansowych (value for money). Znacząca część zakładanych

7 M. Żak, Krótki traktat o dobrobycie, Konin 2012, s. 13.

8 B. Danowska-Prokop, Od liberalnej do keynesowskiej wizji państwa, Katowice 2014, s. 53.

9 Zob. A. Korybski, M. Kostyckij, L. Leszczyński (red.), Pojęcie interesu $w$ naukach prawnych, prawie stanowionym i orzecznictwie sadowym Polski i Ukrainy, Lublin 2006; J. Zimmermann, Prawo administracyjne, Warszawa 2012, s. 273; J. Lang, Struktura prawna skargi $w$ prawie administracyjnym, Wrocław 1972; A. Żurawski, Interes publiczny $w$ prawie gospodarczym, Warszawa 2013; A. Mikołajczak-Waligórska, M. A. Waligórski, Sądowa kontrola umów koncesyjnych motywowana interesem publicznym, [w:] Kontrola zamówień publicznych. Materiaty pokonferencyjne VI Konferencji naukowej UZP, T. Kocowski, J. Sadowy (red.), Wrocław-Warszawa 2013, s. 105-118.

10 S. Dudzik, Działalność gospodarcza samorządu terytorialnego. Problematyka prawna, Kraków 1998, s. 197. 
rezultatów osiągana jest w wyniku poprawnego przeprowadzania procedur przetargowych, natomiast stopień wypełnienia pozostałych zależy od zamawiających, wyrażających swoje potrzeby w odpowiednim ukształtowaniu warunków postępowania przetargowego.

Promowanie prośrodowiskowych rozwiązań jest jednym z przejawów regulacyjnej funkcji państwa. Interwencjonizm państwa związany jest z realizacją interesów ogólnospołecznych oraz z zawodnością rynku. Zakres działań interwencyjnych jest zależny od przyjętych wartości ustrojowych i stanowi konsekwencję wyważenia pomiędzy poziomem administracyjnego oddziaływania państwa a samoregulującymi działaniami rynku (opartego na wolności gospodarczej). Jak wskazał M. A. Waligórski granice ingerencji „wyznaczają obiektywne przesłanki organizacji społecznego procesu gospodarowania"11.

Ingerencja administracyjna związana $\mathrm{z}$ rozwojem zielonego systemu zamówień publicznych wykazuje pewne swoiste cechy, wynikające z dwóch okoliczności:

1) odziaływanie to $\mathrm{w}$ pierwszej kolejności ma charakter pośredni oraz wewnętrzny (zamawiający w znacznej mierze zaliczani są do administracji publicznej sensu $\operatorname{largo}^{12}$ a dokumenty zachęcające do realizacji polityki

11 M.A. Waligórski, Nowe prawo działalności gospodarczej, Poznań 2001, s. 49.

12 Kategoria podmiotów zbiorczo nazwanych przez ustawodawcę zamawiającymi jest w daleko idący sposób zróżnicowana. W obowiązującej ustawie z dnia 29 stycznia 2004 r. Prawo zamówień publicznych (t.j. Dz.U. z 2013 r. poz. 907 ze zm., dalej cyt.: Pzp). zakres podmiotowy ustawy wyznacza art. 3 Pzp wskazujący cztery grupy. W pierwszej grupie znajdują się podmioty państwowe, nie tylko podmioty z administracji rządowej, ale także szeroko rozumianej administracji samorządowej. Drugą grupę stanowią osoby prawne spoza sektora finansów publicznych utworzone w celu zaspokajania potrzeb o charakterze powszechnym niemających charakteru przemysłowego ani handlowego oraz zależne od osób prawa publicznego. Trzecią grupę stanowią podmioty wykonywujące zadania z zakresu działalności użyteczności publicznej, w obrębie wymienionych enumeratywnie sektorów: gospodarki wodnej, energetyki, transportu i usług pocztowych (art. 3 ust. 1 pkt 4 Pzp). Do ostatnie czwartej grupy należą wszystkie podmioty, które spełniają przesłanki wskazane w art. 3 ust. 1 pkt. 5-7 Pzp. Art. 4 Pzp wskazuje zakres podmiotowy oraz zakres przedmiotowy, do których ustawa nie znajduje zastosowa- 
zielonych zamówień publicznych mają charakter strategii, planów), a dopiero następczo może mieć charakter zewnętrzny (na podmioty prywatne, na gospodarkę);

2) sposobu ukształtowania systemu zamówień publicznych (daleko idąca decentralizacja oparta na zasadzie kierownictwa zamawiającego).

Wyeliminowanie pośredniego charakter ingerencji państwowej możliwe jest, poprzez zobligowania zamawiających do pewnych działań (ograniczenie ich swobody). Wskazana praktyka została zastosowana m.in. przy wprowadzeniu rozwiązań nakazującą w szerokim zakresie stosowanie pozacenowych kryteriów oceny ofert ${ }^{13}$. Jednakże zważając na charakter systemu zamówień publicznych, rozwiązanie takie nie tylko może budzić zasadnicze wątpliwości w świetle obowiązującej Konstytucji $\mathrm{RP}^{14}$ ale zdaje się także być wariantem o niskiej skuteczności praktycznej.

W związku z akcesoryjnym charakterem celów pozafinansowych osiąganych w wyniku dokonywania inwestycji, postulować należy kontynuowanie kreowania działań zamawiających poprzez akty prawa miękkiego. Choć nie ma ono prawnie wiążącego charakteru, to wywołuje pewne skutki praktyczne i można uznać, że dopełnia przestrzeń prawną zbudowaną

nia. W związku z powyższym można wskazać na podstawowy podział zamawiających na zamawiających klasycznych oraz zamawiających sektorowych. W związku z charakterem artykułu oraz danymi statystycznymi wskazującymi, że największą grupę zamawiających stanowi administracja samorządowa (64,23\% zamawiających) oraz administracja rządowa terenowa oraz inna, niż jednostka sektora finansów publicznych, państwowa jednostka organizacyjna nieposiadająca osobowości prawnej (po 3,46\% zamawiających), pojęcie zamawiającego na potrzeby niniejszego opracowania ograniczone zostanie do organów administracji publicznej (dane pochodzą z Urząd Zamówień Publicznych: Sprawozdania Prezesa Urzędu Zamówień Publicznych o funkcjonowaniu systemu zamówień publicznych w 2013 r., Warszawa 2014, s. 27).

13 Ustawa z dnia 29 sierpnia 2014 r. o zmianie ustawy - Prawo zamówień publicznych, Dz.U. z 2014 r. poz. 1232. Omówienie wskazanych zmian: zob. K. Różowicz, M. Różowicz, Pozacenowe kryteria oceny ofert. Poradnik dla zamawiających, Poznań 2014.

14 Konstytucja Rzeczypospolitej Polskiej z dnia 2 kwietnia 1997 r., Dz.U. 1997 r. Nr 78, poz. 483 ze zm. 
na podstawie przepisów prawa ${ }^{15}$. Przyjęcie ogólnych strategii na poziomie narodowym integruje działania poszczególnych podmiotów w kierunku osiągania wspólnych celów zgodnych $\mathrm{z}$ interesem publicznym ${ }^{16}$. Poszczególne strategie stanowią pewien generalny koncept systemowego, długofalowego działania władz (i podmiotów współpracujących) wobec szans i zagrożeń wynikających ze zmiennego otoczenia i działań innych podmiotów, ukierunkowany przez przyjęte wartości. Z tych względów plany w sposób istotny determinują działanie administracji publicznej, także w zakresie zamówień publicznych.

Oddziaływanie na zamawiających poprzez akty soft law powinno być połączone z działaniami zmierzającymi do przekonania zamawiających o zasadności, celowości czy też opłacalności realizowania celów określonych w programach strategicznych.

Taki sposób ingerencji państwa nie zwalnia zamawiających z konieczności respektowania regulacji aktów rangi ustawowej oraz podustawowej, także tych, które bezpośrednio nie są zaliczane do aktów kształtujących system zamówień publicznych. Działania administracji powinny być bowiem zgodne z: Konstytucją, ogólnymi zasadami prawa, prawem ustawowym i wydanymi na jej podstawie aktami wykonawczymi (prawem delegowanym), zwyczajami ${ }^{17}$.

\section{OBOWIĄZKI ZAMAWIAJĄCYCH WYNIKAJĄCE Z KONSTYTUCJI RP}

Zamawiający zmierzając do zaspokojenia potrzeb (bezpośrednio bądź pośrednio związanych z potrzebami zbiorowymi

15 M. Błachucki, Stanowienie aktów tzw. prawa miękkiego przez organy administracji publicznej na przykładzie prawa antymonopolowego, [w:] Legislacja administracyjna. Teoria, orzecznictwo, praktyka, M. Stahl, Z. Duniewskiej (red.), Warszawa 2012, s. 242 i nast. -276 .

16 Z. Leoński, Zarys prawa administracyjnego, Warszawa 2000, s. 272-

17 Wyrok NSA z dnia 9 lipca 2008 r., sygn. I OSK 312/08, CBOSA. 
skorelowanymi z interesem publicznym ${ }^{18}$ ), zgodnie $\mathrm{z}$ zasadą legalizmu, której trzon można zrekonstruować na podstawie art. 7 Konstytucji RP, zobowiązani są do podejmowania działań na podstawie i w granicach prawa, w tym zgodnie z Konstytucją RP która wyznacza ramy prawne i ustrojowe funkcjonowania administracji publicznej (rządowej i samorządowej) ${ }^{19}$.

Ze wskazaną zasadą praworządności, koresponduje stworzony przez ustrojodawcę katalog źródeł prawa (art. 87 i 93 Konstytucji RP) oraz reguła bezpośredniego stosowania przepisów Konstytucji RP (art. 8 ust. 2). Ostatnią z nich należy rozpatrywać szerzej także jako obowiązek uwzględnienia rozwiązań ustrojowych w procesie interpretacji przepisów. Nie jest bowiem działaniem organów władzy publicznej „na podstawie i w granicach prawa" takie działanie, które pomija prokonsytucyjną wykładnię prawa ${ }^{20}$. Ustrojowymi ideami zakodowanymi w przepisach Konstytucji mającymi kluczowej znaczenia dla sposobu działań zamawiających są krzyżujące się oraz wzajemnie uzupełniające się, koncepcje społecznej gospodarki rynkowej oraz zrównoważonego rozwoju.

Pomimo, iż polska ustawa zasadnicza ogranicza się jedynie do zwięzłej regulacji niektórych elementów systemu gospodarczego, to jednocześnie bardzo wyraźnie wprowadza wymóg kształtowania określonego porządku gospodarczego, pozostającego w zgodzie z założeniami społecznej gospodarki rynkowej. Artykuł 20 Konstytucji RP stanowi, że podstawą ustroju gospodarczego Rzeczypospolitej Polskiej jest społeczna gospodarka rynkowa oparta na wolności działalności gospodarczej, własności prywatnej oraz solidarności, dialogu i współpracy partnerów społecznych. Oparcie ustroju gospodarczego na koncepcji społecznej gospodarki rynkowej wyznacza określone kierunki

18 Zaspokojenie potrzeb odbywa się przez zapewnienie dostępu całemu społeczeństwu bądź społecznościom lokalnym do dóbr publicznych: „dobra publiczne tworzą konsumpcję zbiorową społeczeństwa, która jest finansowana z funduszy publicznych" (zob. A. Zdebel-Zygmunt, J. Rokicki, System zamówień publicznych $w$ Polsce, Warszawa 2014, s. 21).

19 M. Grzybowski, Administracja publiczna a ład konstytucyjny, [w:] Administracja publiczna, J. Hauser (red.), Warszawa 2005, s. 28.

20 Wyrok NSA z dnia 23 czerwca 2009 r., sygn. I OSK 1254/08, CBOSA. 
i formy oddziaływania organów państwa na system gospodar$\mathrm{czy}^{21}$. Zamierzenie społecznej gospodarki rynkowej uznaje za niemożliwe rozdzielenie ustroju gospodarczego od ustroju społecznego ${ }^{22}$. W przyjętym modelu państwo ma uwzględniać takie wartości jak: wolność gospodarcza, polityczna i religijna, sprawiedliwość społeczna i prawne bezpieczeństwo z zabezpieczeniem społecznym ${ }^{23}$, czy też troska o przyszłość i o środowisko.

Zgodnie z ideą liberalizmu, rozwój gospodarczy rozumie się jako dążenie o charakterze priorytetowym, jednakże uzupełnienie wskazanej idei o koncepcję zrównoważonego rozwoju, będącą kanonem współczesnej polityki ochrony środowiska, doprowadzić ma do rozwoju przy możliwie minimalnym zużyciu naturalnych surowców i energii nieodnawialnych oraz przy możliwie najniższym negatywnym wpływie na środowisko oraz przy najwyższym pozytywnym wpływie na społeczeństwo i środowisko. Zgodnie z ogólnoświatowym trendem, kwestia szeroko pojętej ochrony środowiska została uregulowana w polskiej ustawie zasadniczej ${ }^{24}$. Zarys problematyki zrównoważonego rozwoju $\mathrm{w}$ Konstytucji RP został uwidoczniony bezpośrednio w art. 5 oraz pośrednio w art. 68 oraz art. $74^{25}$. W przywołanych regulacjach określone zostały obowiązki władzy publicznej, które polegają na zapobieganiu negatywnym dla zdrowia skutkom degradacji środowiska, prowadzeniu polityki zapewniającej

21 Por. Z. Witkowski, Prawo konstytucyjne, Toruń 2013, s. 101-106; W. Skrzydło, Polskie prawo konstytucyjne, Warszawa 2010, s. 140-144.

22 K. Strzyczkowski, Konstytucyjna zasada społecznej gospodarki rynkowej jako podstawa tworzenia i stosowania prawa, [w:] Zasady ustroju społecznego $i$ gospodarczego $w$ procesie stosowania Konstytucji, C. Kosikowski (red.), Warszawa 2005, s. 12.

23 S. Partycki, Elementy społeczne w społecznej gospodarce rynkowej, Lublin 1996, s. 12.

24 E. Kubus, J. Kuśnierz-Chmiel, Problematyka ochrony środowiska w wybranych konstytucjach świata, [w:] Ocena modelu prawnego organizacji ochrony środowiska $w$ Polsce $i$ na Słowacji, E. Ura, J. Stelmasiak, S. Pieprzny (red.), Rzeszów 2012, s. 65.

25 Zob. K. Różowicz, Problematyka zrównoważonego rozwoju w ustawodawstwie polskim ze szczególnym uwzględnieniem zagadnień ochrony środowiska, „Morena. Prace Wielkopolskiego Parku Narodowego”, Jeziory 2013, nr 16, s. 65-69. 
bezpieczeństwo ekologiczne współczesnemu i przyszłym pokoleniom, ochronie środowiska oraz wspieraniu działań obywateli na rzecz ochrony i poprawy jego stanu ${ }^{26}$.

Zgodnie ze stanowiskiem WSA w Gorzowie Wielkopolskim wyrażonym w wyroku z dnia 25 marca $2009 \mathrm{r} .^{27}$ do uwzględniania zasady zrównoważonego rozwoju obowiązany jest nie tylko ustawodawca w procesie stanowienia prawa ale także zasadę tę powinny mieć na uwadze organy stosujące prawo. Za podmiot zobowiązany do kształtowania swoich działań zgodnie z przywołaną koncepcją należy uznać także zamawiającego, który stosując normy wynikające z Pzp, udziela zamówienia wykonawcy. Nie sposób bowiem odnaleźć uzasadnienia do pomijania w swych działaniach inwestycyjnych konieczności wyważenia aspektów finansowych, społecznych oraz środowiskowych.

Inkorporowanie zielonych zapisów w dokumentacji przetargowej powinno być zjawiskiem powszechnym w świetle art. 74 ust. 1 Konstytucji RP, który wskazuje, że ochrona środowiska jest obowiązkiem władz publicznych, które powinny prowadzić politykę zapewniającą bezpieczeństwo ekologiczne współczesnemu i przyszłym pokoleniom. Artykuł 74 Konstytucji RP nakłada na władze publiczne (zamawiających) obowiązek prowadzenia polityki, która zapewni bezpieczeństwo ekologiczne zarówno obecnemu społeczeństwu, jak i przyszłym pokoleniom. Treścią ciążącego na władzach publicznych obowiązku ochrony środowiska jest nie tylko wpływanie na podmioty zewnętrzne oraz wspieranie działań społecznych na rzecz ochrony środowiska, ale także, a może i przede wszystkim, podejmowanie różnorodnych kroków mających na celu ochronę środowiska. Władze publiczne oprócz środków mających na celu powstrzymywanie różnych podmiotów od działań szkodzących środowisku, po-

26 M. A. Waligórski, Zezwolenia na działalność inwestycyjna w obszarach natura 2000, [w:] Ocena modelu prawnego organizacji ochrony środowiska w Polsce i na Stowacji, E. Ura, J. Stelmasiak, S. Pieprzny (red.), Rzeszów 2012, s. 457.

27 Wyrok WSA w Gorzowie Wielkopolskim z dnia 25 marca 2009 r., sygn. II SA/Go 825/08, LEX/el. nr 526352. 
winny także podejmować zachowania czynne. Odwołując się do pojęcia organów publicznych, nie można ograniczać konstytucyjnych założeń wyłącznie do podmiotów, których określone zadania oraz kompetencje związane są z ochroną przyrody oraz środowiska. Ponadto nieodzowność uwzględniania aspektów środowiskowych powinna być bliska organom administracji nie tylko w ramach działań bezpośrednio odnoszących się do ochrony przyrody, ale także przy realizacji pozostałych (kształtowaniu infrastruktury, zakupie taboru komunikacji miejskiej itp.). Za przywołaną konstatacją przemawiają nie tylko ustrojowo nałożone obowiązki ale także doświadczenia wykazujące mnogie korzyści z takiego podejścia ${ }^{28}$.

Realizowanie koncepcji zrównoważonego rozwoju przez zamawiających wymaga jednak doprecyzowania wymagań z niej płynących. Jest to zadanie trudne, m.in. dlatego, że zrównoważony rozwój stanowi jedno z licznych przykładów pojęć, które nie doczekały się communis opinio w doktrynie, jak i skonkretyzowanej linii orzeczniczej. W literaturze zarówno ekonomicznej, przyrodniczej, socjologicznej, jak i prawniczej, zostało wypracowanych kilkadziesiąt, jeśli nie kilkaset definicji zrównoważonego rozwoju ${ }^{29}$. Na potrzeby niniejszego opracowania, kluczowe jest odwołanie się do dualistycznego postrzegania koncepcji: wąskiego (pochodzącego od ekorozwoju) i szerokiego (kojarzonego z ładem zintegrowanym).

Węższe postrzeganie koncepcji wiąże się z pojęciem ekorozwoju, pochodzącym od angielskiego eco-development, poprzez które należy przez nie rozumieć rozwój oparty na kryteriach ekologicznych ${ }^{30}$. Ekorozwój definiowany jest jako wzrost gospodarczy, zgodny w wymaganiami ochrony środowiska

28 Egzemplifikacyjne wskazać można na korzyści środowiskowe wynikające z wykorzystania instrumentu e-faktury (zob. K. Różowicz, Wykorzystanie instrumentu e-faktury $w$ systemie prawa zamówień publicznych, „Przegląd Prawniczy, Ekonomiczny i Społeczny" 2014, nr 4, s. 94-95).

29 B. Piontek, Koncepcja rozwoju trwałego i zrównoważonego Polski, Warszawa 2002.

30 S. Kozłowski, Przyszłość ekorozwoju, Lublin 2005, s. 49. 
przyrodniczego ${ }^{31}$. W koncepcjach ekorozwoju, w przypadku wystąpienia konfliktu między elementami składowymi triady, postuluje się prymat wymogów ekologicznych nad postulatami ekonomicznymi czy społecznymi ${ }^{32}$, natomiast w przypadku koncepcji zrównoważonego rozwoju sensu largo konieczne jest osiągnięcie stanu optymalizującego wskazane aspekty, bez zakładania a priori pierwszeństwa któregokolwiek z nich. Zdaniem autora rekonstrukcja norm konstytucyjnych skłania do przyjęcia, iż mowa w nich o koncepcji rozumianej szeroko. Również ustawodawca zwykły w art. 3 pkt 50 ustawy Prawo ochrony środowiska ${ }^{33}$ przychylił się do szerszego pojmowania koncepcji ustrojowej.

Wskazane rozróżnienie posiada istotne znaczenie dla podstaw prawnych stosowania rozwiązań z zakresu zielonych zamówień publicznych. Zamawiający, uwzględniając aspekty środowiskowe w dokumentacji przetargowej, powinien kierować się ostatnim ze wskazanych sposobów rozumienia zrównoważonego rozwoju. Odpowiednie wyważenie istotności aspektów finansowych, środowiskowych oraz społecznych jest konieczne, a przyjęcie $\mathrm{z}$ góry jednego $\mathrm{z}$ nich jako najistotniejszego jest błędem, skutkującym nieefektywnością wydatkowania środków publicznych. Koncepcja zrównoważonego rozwoju wyraża idealną powinność nie opierającą się na hipotezie, że to co nakazane/zakazane musi być w pełni zrealizowane, ale na założeniu realizacji w możliwie najwyższym stopniu uzależnionym od możliwości prawnych oraz faktycznych. Podmiot stosujący prawo dokonuje wyważenia elementów triady i ich skonfigurowania w celu oceny stopnia w jakim możliwe jest dostosowanie swoich działań do założeń ustrojowych. Zamawiający powinien także rozważyć, czy istnieje możliwość zminimalizowania odchyleń od optymalnego poziomu realizacji prośrodowiskowych

31 K. Górka, Polityka ekorozwoju w programach rozwoju gospodarczego, [w:] Sterowanie ekorozwojem. Tom II Zarzadzanie w warunkach ekorozwoju, B. Poskrobko (red.), Białystok 1998, s. 29.

32 T. Borys (red.) Wskaźniki ekorozwoju, Białystok 1999.

33 Ustawa z dnia 27 kwietnia 2001 r. Prawo ochrony środowiska, tj. Dz.U. 2013 r., poz. 1232 ze zm. 
rozwiązań, m.in. w przypadku nieposiadania wystarczających środków finansowych bądź konieczności uwzględnienia w szerszym zakresie elementów socjalnych. Jednocześnie optymalizacja powinna być przeprowadzana nie in abstracto, ale in concreto. Optymalizacja poszczególnych elementów będzie szczególnie istotna w momencie doboru odpowiednich kryteriów oceny ofert oraz przypisywania im odpowiedniej wagi, która powinna obrazować preferencje zamawiającego oraz korespondować z przedmiotem zamówienia. Przedstawiony efekt może zostać osiągnięty m.in. dzięki posłużeniu się jedną z metod optymalizacji wielokryterialnej wypracowanej na płaszczyźnie nauk o ekonomii, np. metodę optymalizacji Pareto.

W literaturze prawa administracyjnego wskazuje się, że organy państwa mogą organizować ochronę prawną polegającą jedynie na spowalnianiu negatywnych procesów konsumpcji, optymalizowaniu wykorzystania dóbr naturalnych oraz minimalizowaniu ilości i jakości uciążliwości degradujących walory naturalne ${ }^{34}$. Obszar troski koncepcji zrównoważonego rozwoju, który powinien być uwzględniany przez zamawiających obejmuje m.in.: rozsądne, tj. obliczone na stosunkowo długi okres (efektywne), wykorzystywanie odnawialnych zasobów przyrody, maksymalizowanie ostrożności w eksploatacji nieodnawialnych źródeł energii, minimalizowanie poziomu emisji zanieczyszczeń np. tlenku węgla, wykorzystywanie ekologicznych materiałów eksploatacyjnych, dopasowanie ilości zamawianych dóbr.

Przedstawiony zakres oddziaływania publicznoprawnego na ochronę środowiska w pełni może być realizowany przez zamawiających. Przetargi publiczne, powinny wspomóc realizację celów prawa ochrony środowiska naturalnego, a tym samym wzajemnie się uzupełniać i wzmacniać. Przyjęcie odmiennej postawy skutkować będzie tym, że koncepcja rozwoju zrównoważonego będzie tylko pustą, nierealizowaną deklaracją, a przynajmniej nierealizowaną w znacznej części. Wdrażanie postanowień składających się na koncepcję zrównoważonego

34 M. A. Waligórski, Działalność gospodarcza $w$ ujęciu prawa administracyjnego, Poznań 2006, s. 148. 
rozwoju może przybierać różnorodne formy w znacznej mierze uzależnione od przedmiotu zamówienia. Spektrum możliwości nabywania dóbr oraz usług przyjaznych środowiskowo jest niezwykle szerokie, od zamówienia artykułów biurowych wykonanych z materiałów biodegradowalnych, poprzez uwzględnienie w dokumentacji projektowej zamówienia na roboty budowlane konieczności montażu instalacji umożliwiających ponowne wykorzystanie szarej wody, na zobowiązaniu wykonawcy realizującego usługi sprzątania do wykorzystana ekologicznych technologii w zakresie środków czystości (m.in. przesuszonej pary) kończąc.

Należy jednak zauważyć, że w przypadku niektórych rodzajów produktów, prac oraz usług wpływ ten może okazać się szczególnie znaczący ze względu na to, że zamówienia publiczne mają ogromny udział w rynku (przykładowo w sektorze komputerów, energooszczędnych budynków, transportu publicznego i tak dalej). O praktycznej możliwości wpływania na postawę przedsiębiorców świadczą doświadczeniach Stanów Zjednoczonych, które już na początku lat 80. dostrzegły duży potencjał tkwiący w zrównoważonych zamówieniach publicznych. Dobitnym przykładem oddziaływania zamówień publicznych na ekologiczne (ale także innowacyjne) zachowania wykonawców jest powszechne wprowadzenie w sprzęcie IT wymagań standardu Energy Star. Od roku 1993, w którym rząd Stanów Zjednoczonych (największy na świecie pojedynczy nabywca komputerów) zdecydował o zakupie wyłącznie sprzętu spełniającego wymogi Energy Star, większość producentów, nie chcąc utracić udziału w rynku IT, wprowadziło zmiany technologiczne w swoich produktach, dostosowując je do wymagań zamawiającego. Według szacunków Amerykańskiej Agencji Ochrony Środowiska wdrożony program Energy Star przyniósł do końca 2012 r. łączne oszczędności w wysokości 2250 mld kWh energii elektrycznej i spowodował zmniejszenie emisji gazów cieplarnianych o 1,8 mld ton ${ }^{35}$.

35 Polska Agencja Rozwoju Przedsiębiorczości, Zamówienia publiczne a innowacyjność MŚP, Warszawa 2013, s.28. 
Istotne miejsce $\mathrm{w}$ działaniach zmierzających do realizacji założeń zrównoważonego rozwoju zajmuje budownictwo. Budownictwo ekologiczne to projektowanie, budowanie i użytkowanie obiektów budowlanych z myślą o ochronie środowiska oraz o zachowaniu jego walorów dla przyszłych poleń. Idea budownictwa zgodnego z zasadami zrównoważonego rozwoju powiązana jest $\mathrm{z}$ rozwojem nowoczesnych technologii wspomagających tworzenie budynków, które nie zanieczyszczają środowiska odpadami i powodują, że użytkowanie obiektów jest przyjazne dla człowieka oraz środowiska. Zastosowanie rozwiązań z zakresu zrównoważonego budownictwa nastawione jest na uzyskanie trwałości i wysokiej jakości rozwiązań materiałowych, konstrukcyjnych, projektowych w celu poprawy istniejących i kształtowania nowych obiektów budowlanych. Cele pośrednie, jakie możliwe są do osiągnięcia, to m.in. ochrona zdrowia mieszkańców, efektywne wykorzystanie energii, wody i innych zasobów naturalnych, ograniczenie ilości odpadów, zanieczyszczeń oraz stopnia degradacji środowiska. Rozwiązania wypracowane w zakresie zrównoważonego budownictwa mogą wspomagać zamówienia publiczne, których przedmiotem są roboty budowlane. Przeniesienie rozwiązań wypracowanych w zakresie zrównoważonego budownictwa może przynieś istotne korzyści m.in. dlatego, że w 2013 roku największą część rynku zamówień publicznych stanowiły zamówienia na roboty budowlane. Jak wynika z rocznych sprawozdań o udzielonych zamówieniach, wartość zakontraktowanych środków na roboty budowlane stanowiła 38\% ogólnej kwoty udzielonych zamówień (w roku 2012 - 45\%; w 2011 - 39\%; w 2010 - 43\%) ${ }^{36}$.

Przywołane przykłady nie tylko umożliwiają uzyskanie świadczeń, które w minimalny sposób wpływają negatywnie na środowisko ale także pozytywnie oddziałują na rynek, co pozostaje w pełnej zgodności z przywołaną już koncepcją społecznej gospodarki rynkowej. Zrównoważona ingerencja w rynek zamówień publicznych, ze względu na jego cechy konstytutywne (w sensie ekonomicznym rynek zamówień publicznych stano-

36 Urząd Zamówień Publicznych, Sprawozdanie Prezesa Urzędu [...] op. cit. 
wi odzwierciedlenie klasycznego rynku ${ }^{37}$ ), pozwala na szersze realizowanie koncepcji sustainable development. Dzięki takim działaniom zamawiających istnieje możliwość zmultiplikowania korzyści z przeprowadzenia jednego postępowania przetargowego. Poprzez wpływanie na rynek podaży, zamawiający może wpłynąć na kształt konkurencji i świadczonych usług oraz oferowanych dóbr. Przywołane działania, można ocenić także w kategorii propagowania idei zrównoważonego rozwoju oraz rozszerzenia zakresu podmiotów realizujących jej założenia. Uwzględnienie przez wykonawców aspektów środowiskowych powinno w wyniku zachęt przełożyć się także na działania na innych subrynkach i rozwój społecznie odpowiedzialnego biznesu (Corporate Social Responsibility - CSR).

Koncepcja zrównoważonego rozwoju, w okresie od XVII wieku ${ }^{38}$ do dnia dzisiejszego, doznała licznych przeobrażeń, m.in. zakresie instrumentów ją wdrażających. Dlatego politykę zielonych zamówień publicznych w połączeniu z społecznie odpowiedzialnymi zamówieniami ${ }^{39}$ należy uznać za konkretyzację założeń ustrojowych ${ }^{40}$. Dookreślenie możliwych sposobów reali-

37 Zob. H. Zalewski, Prawo zamówień publicznych $w$ polskim systemie zamówień publicznych, Bydgoszcz-Gdańsk 2005, s. 69; J. A. Laskowski, Ekonomiczne aspekty zamówień publicznych, „Zamówienia Publiczne. Doradca” 2000, nr 6, s. 17-25.

38 Korzenie koncepcji zrównoważonego rozwoju upatruje się w siedemnastowiecznej idei gospodarowania lasami, opierającej się na pozyskiwaniu tylu drzew, ile może ponownie wyrosnąć, co miało umożliwić odtwarzanie zasobów leśnych (zob. H. von Corlowitz, Sylvicultura oeconomica oder Haußwirthliche Nachricht und Naturmäßige Anweisung zur Wilden Baum-Zucht, München 2013).

39 Uwzględniające aspekty społeczne, zamówienia publiczne określa się mianem społecznie odpowiedzialnych zamówień publicznych. Ich celem jest przede wszystkim zwalczanie różnych przejawów dyskryminacji i społecznego wykluczenia oraz poprawa warunków pracy.

40 Rozszerzenie gamy mechanizmów sprzyjających realizacji ustrojowej koncepcji zrównoważonego rozwoju o zielone zamówienia publiczne skutkuje także tym, że we wskazanym zakresie będzie ona pośrednio kształtowana przez wyspecjalizowane organy nadzorczo-kontrolne nad rynkiem zamówień publicznych. Do katalogu tych organów należy zaliczyć: Prezesa Urzędu Zamówień Publicznych (zob. K. Różowicz, Administracyjnoprawna kontrola zamówień publicznych przeprowadzana przez Prezesa Urzędu Zamówień Pu- 
zacji polityki zielonych zamówień publicznych w dokumentach strategicznych oraz publikacjach wydawanych przez organy administrujące ma ułatwić zamawiającym realizowania ustrojowych celów. Instytucje zamawiające nie powinny ich treści odczytywać jako nałożenie nowych obowiązków, ale jako środek pomocy w realizacji konstytucyjnie zakreślonych celów.

Kompleksowość działań sprzyjających ochronie środowiska należy rozpatrywać na styku poszczególnych dziedzin prawa np. prawa zamówień publicznych oraz prawa ochrony środowiska. Powyższe powinno skutkować podjęciem szerokiej współpracy pomiędzy resortem ochrony środowiska a Urzędem Zamówień Publicznych. W tym miejscu zasadne zdaje się postulowanie większej aktywności przedstawicieli doktryny prawa ochrony środowiska $\mathrm{w}$ dorobek myśli prawa zamówień publicznych. Kooperacja może przysłużyć się do opracowania dokumentów umożliwiających zwrócenie przez instytucje zamawiające uwagi na najistotniejsze elementy oddziaływania na środowisko. Zaniechanie współpracy może narazić zamawiających na ryzyko zakupu produktów i usług pseudoekologicznych.

\section{PODSUMOWANIE}

Zamawiający jako dysponenci środków publicznych nie są ich właścicielem i nie ponoszą negatywnych skutków decyzji bezpośrednio w swoim budżecie ${ }^{41}$, w związku z czym zobligowani zostali do postępowania zgodnie z uregulowania Pzp. Powyższe nie przekreśla jednak statusu zamawiających będą-

blicznych, [w:] Formy nadzoru i kontroli. Aktualne problemy badawcze, red. Ł. Bolesta, M. Chrzanowski, W. Orłowski, Lublin 2014 r., s. 243-258.) oraz Krajową Izbę Odwoławczą (zob. K. Różowicz, Charakterystyka środków ochrony prawnej przewidzianych przepisami ustawy Prawo zamówień publicznych artykuł przekazany do publikacji w czasopiśmie „Studia Prawa Publicznego” 2014, nr 4).

41 T. Grzeszczyk, Podręcznik zamówień publicznych - Polskie procedury Zarys systemu, Warszawa 1995, s. 24. 
cych organami administracji publicznej, dbającymi o ochronę interesu publicznego oraz realizującymi konstytucyjnie określone idee.

Pomimo, że podjęcie decyzji o włączenie do dokumentacji przetargowej aspektów środowiskowych pozostawione zostało zamawiającemu, nie powinno się apriorycznie takiej możliwości odrzucać. Częstokroć bowiem drobne zmiany w sposobie spełniania świadczenia mogą przynieść daleko idące korzyści. Poczyniona konstatacja nie powinna zostać odczytana jako obowiązek każdorazowego włączenia do dokumentacji przetargowej zapisów pozytywnie wpływających na stan środowiska. W konkretnym postępowaniu przetargowym może bowiem się okazać, że w wyniku dokonanej optymalizacji celów nie jest możliwe bądź opłacalne skorzystanie z zapisów realizujących politykę zielonych zamówień publicznych. Zamawiający powinien jednak pamiętać, że w skład katalogu uprawnień umożliwiających mu „zazielenienie postepowania” wchodzi m.in.: możliwość wyboru trybu postępowania, dopuszczenie składania oferty wariantowej oraz oferty częściowej czy dobór pozacenowych kryteriów oceny ofert ${ }^{42}$. Bogaty katalog środków umożliwiających uwzględnienie licznych aspektów środowiskowych uprawdopodabnia możliwości podjęcia działań sprzyjających ochronie środowiska.

Odpowiednie ukształtowanie dokumentacji przetargowej oraz przeprowadzenie postępowania urealnia szanse na nabycie towarów lub usług zaspokajających w optymalny sposób potrzeby zamawiającego. Jednocześnie podkreślenia wymaga, że praktyka pokazuje, iż uwzględnienie aspektów środowiskowych nie musi skutkować podwyższeniem kosztów zakupionego towaru. Przykładem osiągnięcia realnych oszczędności finansowych oraz środowiskowych dzięki wykorzystaniu kooperacji kilku zamawiających jest zamówienie przeprowadzone przez miasto Amaroussion (Grecja), które ogłosiło wspólnie z innymi 6 podmiotami publicznymi łączny przetarg na zakup papieru

42 K. Różowicz, Aspekty ekoinnowacyjne jako kryterium oceny ofert $w$ prawie zamówień publicznych, „Przegląd Prawa Ochrony Środowiska” 2014, nr 3, s. 93-115. 
$\mathrm{z}$ recyklingu. W postępowaniu o udzielenie zamówienia wyłoniono ofertę spełniającą jednocześnie surowe kryteria ekologiczne oraz ekonomiczne. Cena nabycia towaru w wyniku wykorzystania efektu skali, była niższa o około $20 \%$ aniżeli uzyskiwana przez zamawiających działających samodzielnie. Co więcej, koszt nabycia towarów proekologicznych okazał się niższy niż zakup papieru konwencjonalnego w innych gminach ${ }^{43}$.

\section{BIBLIOGRAFIA}

Błachucki M., Stanowienie aktów tzw. prawa miękkiego przez organy administracji publicznej na przykładzie prawa antymonopolowego, [w:] Legislacja administracyjna. Teoria, orzecznictwo, praktyka, M. Stahl, Z. Duniewskiej (red.) Warszawa 2012.

Borys T. (red.) Wskaźniki ekorozwoju, Białystok 1999.

Centre for European Policy Studies (CEPS), The uptake of green public procurement in the EU27, Bruksela 2012.

Corlowitz H. von, Sylvicultura oeconomica oder Haußwirthliche Nachricht und Naturmäßige Anweisung zur Wilden Baum-Zucht, München 2013.

Danowska-Prokop B., Od liberalnej do keynesowskiej wizji państwa, Katowice 2014.

Dudzik S., Działalność gospodarcza samorządu terytorialnego. Problematyka prawna, Kraków 1998.

Górka K., Polityka ekorozwoju w programach rozwoju gospodarczego, [w:] Sterowanie ekorozwojem. Tom II Zarzadzanie w warunkach ekorozwoju, B. Poskrobko (red.), Białystok 1998.

Grzeszczyk T., Podręcznik zamówień publicznych - Polskie procedury zarys systemu, Warszawa 1995.

Grzybowski M., Administracja publiczna a ład konstytucyjny, [w:] Administracja publiczna, J. Hauser (red.), Warszawa 2005.

Komisja Europejska, Ekologiczne zakupy!, Bruksela 2011.

Korybski A., Kostyckij M., Leszczyński L. (red,), Pojęcie interesu w naukach prawnych, prawie stanowionym i orzecznictwie sądowym Polski i Ukrainy, Lublin 2006.

Kozłowski S., Przyszłość ekorozwoju, Lublin 2005.

43 Komisja Europejska, Ekologiczne zakupy!, Bruksela 2011, s. 23. 
Kubus E., Kuśnierz-Chmiel J., Problematyka ochrony środowiska w wybranych konstytucjach świata, [w:] Ocena modelu prawnego organizacji ochrony środowiska $w$ Polsce i na Stowacji, E. Ura, J. Stelmasiak, S. Pieprzny (red.), Rzeszów 2012.

Lang J., Struktura prawna skargi wprawie administracyjnym, Wrocław 1972.

Laskowski J. A., Ekonomiczne aspekty zamówień publicznych, „Zamówienia Publiczne. Doradca" 2000, nr 6.

Leoński Z., Zarys prawa administracyjnego, Warszawa 2000.

Mikołajczak-Waligórska A., Waligórski M. A., Sądowa kontrola umów koncesyjnych motywowana interesem publicznym, [w:] Kontrola zamówień publicznych. Materiaty pokonferencyjne VI Konferencji naukowej UZP, T. Kocowski, J. Sadowy (red.), Wrocław- Warszawa 2013.

Partycki S., Elementy społeczne $w$ społecznej gospodarce rynkowej, Lublin 1996.

Piontek B., Koncepcja rozwoju trwałego i zrównoważonego Polski, Warszawa 2002.

Polska Agencja Rozwoju Przedsiębiorczości, Zamówienia publiczne a innowacyjność MŚP, Warszawa 2013.

Różowicz K., Wykorzystanie instrumentu e-faktury $w$ systemie prawa zamówień publicznych, „Przegląd Prawniczy, Ekonomiczny i Społeczny" 2014, nr 4.

Różowicz K., Administracyjnoprawna kontrola zamówień publicznych przeprowadzana przez Prezesa Urzędu Zamówień Publicznych, [w:] Formy nadzoru i kontroli. Aktualne problemy badawcze, Ł. Bolesta, M. Chrzanowski, W. Orłowski (red.), Lublin 2014.

Różowicz K., Aspekty ekoinnowacyjne jako kryterium oceny ofert w prawie zamówień publicznych, „Przegląd Prawa Ochrony Środowiska" 2014, nr 3.

Różowicz K., Charakterystyka środków ochrony prawnej przewidzianych przepisami ustawy Prawo zamówień publicznych, „Studia Prawa Publicznego" 2014, nr 4.

Różowicz K., Problematyka zrównoważonego rozwoju w ustawodawstwie polskim ze szczególnym uwzględnieniem zagadnień ochrony środowiska, „Morena. Prace Wielkopolskiego Parku Narodowego", Jeziory 2013, nr 16.

Różowicz K., Różowicz M., Pozacenowe kryteria oceny ofert. Poradnik dla zamawiajacych, Poznań 2014.

Różowicz K., System zamówień publicznych $w$ ochronie środowiska, z uwzględnieniem projektu poselskiego zmian ustawy Prawo zamówień publicznych, http://zlppn.pl/prawo.htm. 
Rudnicki M., Ochrona środowiska we wspótczesnej polityce władz publicznych, [w:] Administracja publiczna - człowiek a ochrona środowiska. Zagadnienia społeczno-prawne, M. Górski, J. Bucińska, M. Niedziółka, R. Stec, D. Strus (red.), Warszawa 2011.

Skrzydło W., Polskie prawo konstytucyjne, Warszawa 2010.

Strzyczkowski K., Konstytucyjna zasada społecznej gospodarki rynkowej jako podstawa tworzenia i stosowania prawa, [w:] Zasady ustroju społecznego i gospodarczego $w$ procesie stosowania Konstytucji, C. Kosikowski (red.), Warszawa 2005.

Urząd Zamówień Publicznych, Krajowy Plan Działań w zakresie zrównoważonych zamówień publicznych 2013-2016, Warszawa 2013.

Urząd Zamówień Publicznych, Sprawozdania Prezesa Urzędu Zamówień Publicznych o funkcjonowaniu systemu zamówień publicznych $w 2013$ r., Warszawa 2014.

Waligórski M. A., Działalność gospodarcza $w$ ujęciu prawa administracyjnego, Poznań 2006.

Waligórski M. A., Nowe prawo działalności gospodarczej, Poznań 2001. Waligórski M. A., Zezwolenia na działalność inwestycyjna $w$ obszarach natura 2000, [w:] Ocena modelu prawnego organizacji ochrony środowiska w Polsce i na Stowacji, E. Ura, J. Stelmasiak, S. Pieprzny (red.), Rzeszów 2012.

Witkowski Z., Prawo konstytucyjne, Toruń 2013.

Zalewski H., Prawo zamówień publicznych $w$ polskim systemie zamówień publicznych, Bydgoszcz-Gdańsk 2005.

Zdebel-Zygmunt A., Rokicki J., System zamówień publicznych w Polsce, Warszawa 2014.

Zimmermann J., Prawo administracyjne, Warszawa 2012.

Żak M., Krótki traktat o dobrobycie, Konin 2012.

Żurawski A., Interes publiczny w prawie gospodarczym, Warszawa 2013.

Kontakt e-mail

rozowicz@o2.pl 